\section{Estudo \\ cabebate}

em Cestão

Planejamento
Revista Estudo \& Debate, Lajeado, v. 27, n. 4, 2020. ISSN 1983-036X DOI: http://dx.doi.org/10.22410/issn.1983-036X.v27i4a2020.2574

\title{
O COMPLIANCE NO ÂMBITO DAS RELAÇÓES DE EMPREGO: O PODER EMPREGATÍCIO E SUAS DISPOSIÇÓES NA LEGISLAÇÃO BRASILEIRA E ARGENTINA
}

\author{
Felipe Augusto Silva Custódio ${ }^{1}$
}

\begin{abstract}
Resumo: O presente artigo tem por objetivo analisar a adequaçáo dos programas de compliance dentro das disposiçôes trabalhistas na legislação brasileira e argentina, com foco nas relaçôes de emprego e, elencar em qual poder empregatício os programas de compliance se adequam. Nesse sentido, o artigo enumera e explica a relaçáo de emprego, que é uma espécie da relação de trabalho e, compara o poder empregatício no ordenamento jurídico brasileiro e argentino, apontando as semelhanças, diferenças e possíveis omissóes. Sucessivamente, será tratado o papel dos programas de compliance, que possuem como parâmetro principal a prevenção a possíveis desvios entre as normas estabelecidas pelas instituiçóes e, as condutas praticadas nos casos concretos pelas pessoas físicas ou jurídicas dentro destas instituiçóes.
\end{abstract}

Palavras-chave: Direito do Trabalho. Programas de compliance. Relação de emprego. Poder empregatício. Legislação brasileira. Legislação argentina.

\section{COMPLIANCE WITHIN EMPLOYMENT RELATIONS: EMPLOYMENT POWER AND ITS PROVISIONS IN BRAZILIAN AND ARGENTINE LEGISLATION}

\begin{abstract}
The purpose of this article is to analyze the adequacy of compliance programs within the labor provisions in Brazilian and Argentine legislation, with a focus on employment relationships and to list in which power the compliance programs are suitable. In this sense, the article lists and explains the employment relationship, which is a kind of employment relationship, and compares employment power in the Brazilian and Argentine legal systems, pointing out the similarities, differences and possible omissions. Subsequently, the role of compliance programs will be addressed, whose main parameter is the prevention of possible deviations between the rules established by the institutions and the conduct practiced in specific cases by individuals or legal entities within these institutions.
\end{abstract}

Keywords: Labor Law. Compliance programs. Employment relationship. Employment power. Brazilian legislation. Argentine legislation.

1 Graduado em Direito pelo Centro Universitário de Sete Lagoas/UNIFEMM. Pós-graduado em Direito e Processo do Trabalho pelo Centro Universitário UNA de Sete Lagoas. Pós-graduado Direito Tributário pela PUC/MG. Mestre em Direito pela Faculdade de Direito Milton Campos. Professor de Direito do Trabalho e Direito Empresarial. Advogado. 


\section{INTRODUÇÁO}

O poder empregatício encontra amparo no Direito do Trabalho brasileiro a partir do artigo $2^{\circ}$ da Consolidaçáo das Leis do Trabalho, designada como CLT (Decreto Lei ${ }^{\circ}$ 5.452/1943), que dispóe que o empregador é destinatário de várias normas intrínsecas à relação de emprego, em face do seu poder de direção, regulação, fiscalização e disciplinar no âmbito do vínculo empregatício contratual com o seu empregado. Sucessivamente, a Lei no 20.744 (principal lei trabalhista argentina), designada como Lei do Contrato de Trabalho argentino, destaca a partir do seu artigo $1^{\circ}$, que os contratos de trabalho daquele território, serão regidos dentre outras normas, por leis, acordos e convençôes coletivas, contratos individuais de trabalho e, por normas intrínsecas à relaçáo de trabalho e emprego.

Além das disposiçôes feitas pelas leis trabalhistas destes estados, a doutrina majoritária destes países, as quais tratam sobre as normas trabalhistas, dispóem a partir do limite tanto constitucional, trabalhista, cível e penal, em que os empregadores poderão adotar procedimentos para dirigir, regular, fiscalizar e disciplinar as relaçóes jurídicas trabalhistas. Nesse norte, torna-se importante mencionar os aspectos do poder empregatício inerentes ao empregador, veja-se: i) poder diretivo; ii) poder regulamentar; iii) poder fiscalizatório e, iv) poder disciplinar.

Nesse esteio, atualmente os empregadores utilizam os programas de compliance, que em sua acepçáo principal, está relacionado de maneira direta e vinculada ao cumprimento das diretrizes, normas e regramentos internos das empresas (empregador), como meio de determinar quais normas, regras e diretrizes internas serão aceitas e, que deveráo ser adotadas pelos empregados daquela determinada instituiçáo empregatícia.

Considerando que o contrato de trabalho, tanto na legislação brasileira, como no ordenamento argentino é um acordo de vontades, podendo ser tácito ou expresso, escrito ou verbal e, feito de forma bilateral, este terá tanto deveres, como obrigaçóes, em face de sua concordância, o qual terá como um de seus pilares a boa-fé entre os seus pactuantes.

Nesse sentido, a hipótese que pretende responder ao tema-problema em que foi fixado o recorte epistemológico do presente artigo é: i) os programas de compliance adequam-se dentro do poder empregatício; ii) os programas de compliance estáo relacionados em qual ramificação do poder empregatício.

Para realizar tal intento e cumprir os parâmetros propostos, analisaram-se a principal legislação trabalhista de cada estado, qual seja do Brasil (Decreto Lei no 5.452/1943) e, da Argentina (Lei no 20.744/1976), bem como o que cada doutrina destes países tratam sobre tal matéria, elencando premissas para a sua regulação dentro da relação de emprego.

Nesse norte, utiliza-se como metodologia o método jurídico teórico, com o exame da legislação, das doutrinas trabalhistas e constitucionais existentes sobre o tema em cada país citado anteriormente, bem como a análise de dados decorrentes de pesquisa indireta sobre o poder empregatício e, sobre os programas de compliance utilizados pelos empregadores. 


\title{
2 O PODER EMPREGATÍCIO NAS RELAÇÓES DE EMPREGO
}

No que tange à leitura das normas trabalhistas, a exemplo da legislação trabalhista brasileira e argentina, que é o foco do presente artigo, percebe-se que tanto as relaçóes de trabalho e, as relaçóes de emprego, possuem como norte e, aspecto doutrinário e jurisprudencial algumas disposiçōes específicas à matéria, como as fontes, princípios, diretrizes, efeitos e regulaçóes intrínsecas aos vínculos empregatícios nas relaçôes de emprego, bem como as disposiçôes específicas que são inerentes às relaçóes de trabalho.

Nesse aspecto, tem-se que o poder empregatício, que está ligado as prerrogativas inerentes ao empregador, que deverão ser observadas pelo empregado em uma relação de emprego, visto a bilateralidade das obrigaçóes do contrato de trabalho.

Nessa esteira, Carlos Henrique Bezerra Leite (2019, p 591) destaca o contrato individual de trabalho como o negócio jurídico regulado pelo direito do trabalho, que estabelece um conjunto de direitos e deveres para o empregado e para o empregador.

Nesse mesmo sentido, De Plácido e Silva explica:

\begin{abstract}
O contrato de trabalho se dá ao ajuste promovido entre empregado e empregador, com base no Direito Privado e apoio do poder público, em virtude do qual uma ou mais pessoas se colocam à disposição de outra ou de outras, para prestar, sob sua dependencia e instruçóes, qualquer trabalho de ordem material ou física, ou de ordem intelectual, em troca de uma remuneração, previamente estabalecida (SILVA, 2013, p. 382).
\end{abstract}

A doutrina majoritária argentina, a exemplo destacada por Julio Armando Grisolia, explica no mesmo sentido acima descrito, em face da conceituaçáo do contrato de trabalho, acrescendo em tal conceituação o objeto do contrato:

\begin{abstract}
Constituye una relación jurídica típica que genera obligaciones de características predeterminadas por la ley y que se compone de los siguientes elementos essenciales: i) sujetos: trabajador y empleador; ii) objeto: la prestaciónde trabajo en condiciones de subordinación, y; iii) causa final: que es para el empleador la apropiación del resultado del trabajo prestado y, para el trabajador, la percepción de una remuneración (GRISOLIA, 2014, p. 99).
\end{abstract}

Em face da disposição que o contrato de trabalho possui prerrogativas, obrigaçôes e deveres a serem cumpridos por aqueles que o integram ${ }^{2}$, independente se tal contrato é individual ou coletivo, as obrigações decorrentes daquele pacto contratual deverão ser cumpridas pelas partes, baseando-se, necessariamente, na boa-fé objetiva.

Dessa forma, o poder empregatício decorre exatamente da função do contrato de trabalho oriunda de uma relaçáo de emprego, em que o empregador, seja ele pessoa física ou jurídica, dispóe de prerrogativas emanadas pelas normas, em que ele poderá utilizar de dispositivos, regras, normas e procedimentos, sejam eles internos ou externos, para direcionar aquele empreendimento, tanto de maneira individual, como coletiva.

2 Art. 104. A validade do negócio jurídico requer: I - agente capaz; II - objeto lícito, possível, determinado ou determinável; III - forma prescrita ou não defesa em lei. (BRASIL, 2002). 
Nesse sentido, Ricardo Resende explica o poder empregatício:

O poder empregatício decorre do contrato de trabalho, consistindo no conjunto de prerrogativas conferidas ao empregador no sentido da direção da prestação dos serviços. Portanto, o fundamento do poder empregatício é, para a doutrina amplamente majoritária, o próprio contrato de trabalho, consubstanciando em im acordo de vontades que origina a relação empregatícia e, a partir desta, faz surgir direitos e deveres para os contratantes (empregador e empregado). Neste complexo de direitos e obrigaçóes encontra-se inserido o poder empregatício (REZENDE, 2014, p. 307).

Torna-se importante destacar que, mesmo o poder empregatício decorrendo de uma relação empregatícia, ou seja, decorrente de um pacto contratual trabalhista de emprego, tal poder é inerente de maneira única e, exclusiva, as prerrogativas emanadas pela norma ao empregador, o qual possui o poder diretivo, regulamentar, fiscalizatório e disciplinar da empresa, conforme doutrina majoritária brasileira.

Desta feita, percebe-se a relevância do poder empregatício nas relaçóes de emprego, que na legislaçáo brasileira decorre do acúmulo de cinco requisitos, quais sejam: i) não eventualidade; ii) pessoalidade; iii) onerosidade; iv) subordinaçáo e; v) trabalho prestado por pessoa física.

A não eventualidade ${ }^{3}$, conforme é tratado na doutrina majoritária na esfera trabalhista brasileira, decorre do labor contínuo ao empregador, devendo, atender as disposiçóes elencadas no pacto contratual. Sucessivamente, a pessoalidade ${ }^{4}$ (intuitu personae) decorre da disposição em que o empregado não pode se fazer substituir naquela relaçáo empregatícia, ou seja, somente ele deverá prestar os serviços ao empregador.

A onerosidade $e^{5}$ dispóe que enquanto o empregado disponibiliza, vende a sua mão de obra, em contrapartida, este recebe seu salário/remuneração. Já, a subordinaçãa ${ }^{6}$ decorre

3 A continuidade revela-se pela permanência em certo decurso de tempo do labor prestado pelo empregado ao seu empregador. Continuidade é trabalho dia após dia, a CLT não adotou esta teoria para conceituar empregado, portanto, adota a teoria da permanência, ou seja, basta que o empregado trabalhe no local sem eventualidade. Pelo princípio da continuidade da relaçáo de emprego, o empregado vincula-se ao empregador por prazo indeterminado. (CALVO, 2013, p. 12).

4 O contrato de emprego é pessoal em relaçáo ao empregado. Isto quer dizer que aquele indivíduo foi escolhido por suas qualificaçôes pessoais ou virtudes (formação técnica, acadêmica, perfil profissional, personalidade, grau de confiança que nele é depositada etc.). É contratado para prestar pessoalmente os serviços, não podendo ser substituído por outro qualquer de sua escolha, aleatoriamente. Todavia, pode o empregador pôr um substituto de sua escolha ou aquiescer com a substituição indicada pelo trabalhador. Isto quer dizer que o contrato é firmado com certa e determinada pessoa. (CASSAR, 2018, p. 48-49).

5 Onerosidade é um encargo bilateral próprio da relaçáo de emprego. Significa, para o empregado, o dever de exercer uma atividade por conta alheia cedendo antecipadamente ao beneficiário os direitos que eventualmente teria sobre os resultados da produção, em troca de uma remuneração. (NASCIMENTO, 2011, p. 650).

6 Em face do poder de comando do empregador, o empregado tem o dever de obediência, mesmo que tênue (altos empregados), ou em potencial (profissionistas), podendo aquele dirigir, fiscalizar a prestação de serviços, bem como punir o trabalhador. (CASSAR, 2018, p. 49). 
das orientações hierárquicas advindas de um superior, que em alguns casos será o próprio proprietário da empresa e/ou aquele que possui poderes para tal ato. Por último é o requisito do trabalho prestado por pessoa física ${ }^{7}$, que dispóe que a relaçáo de empregado será entre a pessoa jurídica e a pessoa física, ou, pessoa física e pessoa física, visto que se a relação decorrer entre pessoas jurídicas, será no mínimo uma prestação de serviços e não uma relação de emprego.

Em face dos requisitos descritos acima, é possível perceber na legislação argentina, bem como na doutrina majoritária deste país, que os requisitos utilizados para caracterização das relações de emprego são as mesmas e, de igual forma a sua conceituação, conforme se verifica no artigo $21 \mathrm{da}$ LCT argentina:

Habrá contrato de trabajo, cualquiera sea su forma o denominación, siempre que una persona física se obligue a realizar actos, ejecutar obras o prestar servicios en favor de la otra y bajo la dependencia de ésta, durante un período determinado o indeterminado de tiempo, mediante el pago de una remuneración. Sus cláusulas, en cuanto a la forma y condiciones de la prestación, quedan sometidas a las disposiciones de orden público, los estatutos, las convenciones colectivas o los laudos con fuerza de tales y los usos y costumbres (ARGENTINA, 1976).

Dessa forma, passa-se a expor de maneira específica e individualizada sobre o poder empregatício no ordenamento jurídico trabalhista brasileiro, bem como a sua relevância e, relação com as disposiçóes inerentes às prerrogativas dos empregadores, conforme destacado anteriormente, visto que tal poder é exclusivo, ou seja, próprio daquele que efetua a contratação por meio do contrato de trabalho.

\section{1 $O$ poder empregatício no ordenamento trabalhista brasileiro}

Sabe-se, conforme elencado no tópico anterior, que o poder empregatício está intimamente relacionado as prerrogativas que o empregador possui em uma relação de emprego, ou seja, tal poder emana da relação de emprego. A principal norma trabalhista brasileira (Decreto Lei no 5.452/1943), bem como a doutrina e jurisprudência, dispóem de quatro tipos de poderes pertencentes ao poder empregatício nas relaçóes trabalhistas, que são: i) poder diretivo; ii) poder regulamentar; iii) poder fiscalizatório e; iv) poder disciplinar.

Legitimando a base de tais poderes, a norma trabalhista positivou vários preceitos inerentes ao empregador, podendo citar alguns artigos específicos da CLT que tratam da matéria, como o artigo $2^{\circ}, 3^{\circ}, 6^{\circ}, 442$ e 444 . Veja-se:

Art. $2^{\circ}$ - Considera-se empregador a empresa, individual ou coletiva, que, assumindo os riscos da atividade econômica, admite, assalaria e dirige a prestação pessoal de serviço.

Art. $3^{\circ}$ - Considera-se empregado toda pessoa física que prestar serviços de natureza não eventual a empregador, sob a dependência deste e mediante salário.

7 Art. 593. A prestação de serviço, que não estiver sujeita às leis trabalhistas ou a lei especial, reger-se-á pelas disposiçóes deste Capítulo. (BRASIL, 2002). 
Art. 6o Não se distingue entre o trabalho realizado no estabelecimento do empregador, o executado no domićlío do empregado e o realizado a distância, desde que estejam caracterizados os pressupostos da relação de emprego.

Art. 442 - Contrato individual de trabalho é o acordo tácito ou expresso, correspondente à relação de emprego.

Art. 444 - As relaçóes contratuais de trabalho podem ser objeto de livre estipulação das partes interessadas em tudo quanto não contravenha às disposiçóes de proteção ao trabalho, aos contratos coletivos que lhes sejam aplicáveis e às decisóes das autoridades competentes. (BRASIL, 1943).

Tais artigos demonstram a responsabilidade que o empregador possível perante a relação de emprego, o qual assume os riscos do empreendimento, dirige as atividades laborais dos seus empregados, regula por meio de normas e regras as condutas individuais e coletivas dos seus empregados, bem como fiscaliza e disciplina ${ }^{8}$ se tais normas estão sendo cumpridas pelos seus empregados.

Nessa sentido, Maurício Godinho Delgado explica:

Poder empregatício é o conjunto de prerrogativas asseguradas pela ordem jurídica e tendencialmente concentradas da figura do empregador, para exercício no contexto da relação de emprego. Pode ser conceituado, ainda, como o conjunto de prerrogativas com respeito à direção, regulamentação, fiscalização e disciplinamento da economia interna à empresa e correspondente prestação de serviços (GODINHO, 2015, P. 710).

\section{Utilizando-se da mesma forma conceitual, Ricardo Resende ensina:}

O poder diretivo é o poder de dirigir a organização da estrutura e do espaço interno da empresa, bem como do processo de trabalho, pelo qual o empregador comanda a energia de trabalho do empregado no sentido que melhor lhe aproveite. O poder regulamentar é o poder de fixar regras gerais a serem seguindas no âmbito da empresa. O poder fiscalizatório, é o poder de vigilância em relação ao ambiente interno da empresa e a prerrogativa que tem o empregador de fiscalizar o modo de prestaçáo dos serviços. O poder disciplicar, é o poder que o empregador tem de aplicar puniçóes aos empregados em caso de descrumprimento de suas obrigaçôes contratuais (RESENDE, 2014, p. 308-312).

Desta feita, percebe-se que os quatro poderes pertencentes ao poder empregatício visam a dar segurança ao empregador na execução lato sensu do seu empreendimento, visto

8 Art. 482 - Constituem justa causa para rescisão do contrato de trabalho pelo empregador: a) ato de improbidade; b) incontinência de conduta ou mau procedimento; c) negociação habitual por conta própria ou alheia sem permissão do empregador, e quando constituir ato de concorrência à empresa para a qual trabalha o empregado, ou for prejudicial ao serviço; d) condenação criminal do empregado, passada em julgado, caso não tenha havido suspensão da execução da pena; e) desídia no desempenho das respectivas funçôes; f) embriaguez habitual ou em serviço; g) violação de segredo da empresa; h) ato de indisciplina ou de insubordinação; i) abandono de emprego; j) ato lesivo da honra ou da boa fama praticado no serviço contra qualquer pessoa, ou ofensas físicas, nas mesmas condiçóes, salvo em caso de legítima defesa, própria ou de outrem; k) ato lesivo da honra ou da boa fama ou ofensas físicas praticadas contra o empregador e superiores hierárquicos, salvo em caso de legítima defesa, própria ou de outrem; 1) prática constante de jogos de azar. m) perda da habilitação ou dos requisitos estabelecidos em lei para o exercício da profissão, em decorrência de conduta dolosa do empregado. (BRASIL, 1943). 
que o empregador diferentemente do empregado é a parte da relação de emprego que é mais dotada de ferramentas e conhecimentos inerentes àquele tipo específico de negócio.

A propósito, é importante relacionar no direito brasileiro o poder empregatício com o artigo 442 da CLT, o qual um para existir, efetivamente dependerá do outro, porque sem relação de emprego, não há que se falar em poder empregatício, o que faz lembrar que em um relação de trabalho, tendo em vista a falta de um ou mais requisitos da relação de emprego, não haverá poder empregatício.

A própria jurisprudência ${ }^{9}$ nacional, utiliza dos conceitos do poder empregatício para legitimar as hipóteses e distinçóes entre a relação de trabalho e, a relação de emprego. Nesse passo, em face dos dispositivos elencados pela norma, doutrina e jurisprudência, o poder empregatício na relação de emprego é medida necessária para a concretização dos objetivos propostos pela instituição.

\section{2 $O$ poder empregatício na legislação argentina}

O poder empregatício na legislação argentina também decorre de uma relação de emprego e, não de uma relação de trabalho. A relação de trabalho no ordenamento jurídico argentino, possui os mesmos parâmetros da legislação brasileira, conforme tratado no tópico anterior.

Nesse aspecto, o artigo $4^{\mathrm{o}^{10}}, 5^{\mathrm{o}^{11}}$ e 21 da LCT é claro quando dispóe sobre o conceito de empregador e empregado, o qual elenca alguns requisitos mínimos para tal reconhecimento: i) contrato de trabalho consensual; ii) poder de direçáo/administraçáo/ organização; iii) atividade produtiva e remunerada ao empregado; iv) dependência do empregado ao empregador; v) subordinação; vi) pessoalidade.

9 REPRESENTANTE COMERCIAL. SUBORDINAÇÃO JURÍDICA. PODERES EMPREGATÍCIOS. AUSÊNCIA. VÍNCULO DE EMPREGO. NÃO CONFIGURAÇĀO. Considerando que a onerosidade, a pessoalidade e a não eventualidade são características comuns ao empregado subordinado e ao representante comercial, o único traço distintivo entre ambas as formas de trabalho reside na subordinação jurídica decorrente do exercício dos poderes diretivo e hierárquico, os quais não restaram evidenciados na hipótese dos autos, conduzindo ao não reconhecimento do vínculo empregatício. Recurso não provido. (TRT-13 RO: 00008692420185130008 0000869-24.2018.5.13.0008, 2a Turma, Data de Publicação: 19/09/2019). Disponível em:< https://trt-13.jusbrasil.com.br/jurisprudencia/759728723/recurso-ordinario-trabalhistaro-8692420185130008-0000869-2420185130008?ref=serp>. Acesso em 20/03/2020.

10 Art. $4^{\circ}$ - Concepto de trabajo: Constituye trabajo, a los fines de esta ley, toda actividad lícita que se preste en favor de quien tiene la facultad de dirigirla, mediante una remuneración.

El contrato de trabajo tiene como principal objeto la actividad productiva y creadora del hombre en sí. Sólo después ha de entenderse que media entre las partes una relación de intercambio y un fin económico en cuanto se disciplina por esta ley. (ARGENTINA, 1976).

11 Art. $5^{\circ}$ - Empresa-Empresario. A los fines de esta ley, se entiende como "empresa" la organización instrumental de medios personales, materiales e inmateriales, ordenados bajo una dirección para el logro de fines económicos o benéficos. A los mismos fines, se llama "empresario" a quien dirige la empresa por sí, o por medio de otras personas, y con el cual se relacionan jerárquicamente los trabajadores, cualquiera sea la participación que las leyes asignen a éstos en la gestión y dirección de la "empresa". (ARGENTINA, 1976). 
Dessa forma, Julio Armando Grisolia explica:

La ley considera que quien trabaja en relación de dependencia celebró con anterioridade por lo menos un acuerdo tácito, que resulta válido ya que el contrato de trabajo es, por esencia, informal. En consequencia, el hecho de efectivizarse la puesta a disposición de la fuerza de trabajo por parte del trabajador, a favor del empleador, y a cambio del pago de la remuneración, configura la situación contemplada en el art. 22, LCT (GRISOLIA, 2016, p. 102).

Percebe-se que o poder empregatício na doutrina argentina também está relacionada de maneira direta ao empregador, conforme disposto na norma brasileira, porém, em tal ordenamento, o poder empregatício é inerente ao poder de direção/administração/ organizaçáo ${ }^{12}$ da empresa pelo empregador, bem como a utilizaçáo do poder de disciplinar na atividade empresarial relacionada ao contrato de trabalho ${ }^{13}$.

$\mathrm{O}$ poder de direção ${ }^{14} / \mathrm{administração/organização} \mathrm{no} \mathrm{ordenamento} \mathrm{trabalhista}$ argentino, disserta que é prerrogativa do empregador, coordenar como um todo a operação do seu empreendimento, além da tomada de decisóes, como também a criação de normas e regulamentos internos como meio disciplinar as atividades e condutas dos empregados.

Nesse sentido, Julián Arturo de Diego (2011, p. 223) explica que "los poderes del empleador son el conjunto de poderes o atribuciones que tiene el empleador en función de los cuales ejerce el principio de autoridad como titular de los bienes de la producción, a fin de que los recursos humanos, combinados armónicamente con los recursos técnicos y los económicos, permitan el logro del fin de la empresa, consistente en la producción de bienes y de servicios."

12 La LCT reconoce al empleador las facultades de dirección, organización y el ejercicio del poder disciplinario y el ius variandi como atribuciones propias de quien es el titular del capital y la tecnología, y por ende es quien ejerce la autoridade para ordenar los recursos humanos y las máquinas y equipos para producir bienes y servicios (arts. 64, 65, 66 y 67, LCT).

Sin embargo, todas estas atribuciones están limitadas a continuación de su enunciado, instando al empleador a actuar con razonabilidad, destacando el respeto por los derechos personales y patrimoniales del trabajador, o poniendo limites en cuanto que los cambios no pueden producir daños morales o materiales a sus dependientes.

13 El contrato de trabajo está conformado por el acuerdo de voluntades que tiene por fin reglar los deberes y derechos de las partes. En nuestro sistema legal, la mayoría de las obligaciones de las partes estás enunciadas en la LCT y en el marco de los estatutos especiales y los convênios colectivos. (DIEGO, 2011, p. 218).

14 Es la potestad del empleador de impartir a través del principio de autoridad, las órdenes e instrucciones que sean necesarias para que los recursos humanos de la empresa puedan, armónicamente, producir los bienes y servicios a partir de los equipos y maquinarias disponibles. (DIEGO, 2011, p. 223). 
Já, o poder disciplinar ${ }^{15}$ possui a mesma conceituação que é utilizada pela doutrina brasileira, o qual tal poder está relacionado ao dever do empregado em cumprir com as diretrizes propostas pelo empregador, o qual caso não cumpra, será advertido.

Dessa forma, o poder empregatício na norma argentina também está relacionado com a relação de emprego e, nasce com o contrato de trabalho, o qual prevê as condutas esperadas tanto pelo empregador, como pelo empregado naquele vínculo contratual.

\section{COMPLIANCE}

Os programas de compliance despertam umas das fases mais importantes inerentes à regulação das condutas éticas nas empresas, utilizando-se de ferramentas para regular as condutas daqueles que integram as empresas, sejam pessoas físicas ou jurídicas.

O termo compliance deriva da cultura inglesa ${ }^{16}$, que possui como significado "agir de acordo com", ou seja, agir de acordo com uma norma interna da empresa/instituição, ou, de normas externas à relação de emprego.

Alexandre Alkmim Teixeira explica sobre o tema compliance:

O termo compliance tem sido largamente utilizado no mundo corporativo para se referir à conduta da empresa que se porta conforme as normas e àquilo que é esperado pela sociedade com relaçáo à sua postura negocial e social. Trata-se, pois, de um termo cuja amplitude permite desdobramentos nas mais diversas áreas: negocial, trabalhista, ambiental, concorrencial, tributária, dentre outras. Assim, compliance vai além do mero cumprimento da lei. A empresa que possui compliance busca demonstrar não apenas a sua regularidade legal, mas, também, o seu comprometimento em atender às expectativas morais da sociedade em que ela está inserida (TEIXEIRA, 2019, p. 31).

Os programas de compliance utilizam tanto de normas, regulamentos, cartilhas e códigos de condutas internos, como de normas externas, com o objetivo de coibir a possíveis atos ilícitos daqueles que possuem qualquer relação com a instituição.

Nesse esteio, Gustavo Badaró e Pierpaolo Bottini (2016, p. 52) destacam que o escopo das políticas de compliance é o de garantir, sob uma perspectiva ex ante, o cumprimento das normas direcionadas à área de atuação de determinada instituiçáo, a fim de evitar problemas jurídicos e de imagem decorrentes de falhas de organização interna que coloquem a empresa em situação de conflito com os atos regulatórios.

15 Es la facultad discrecional del empleador, emergente del principio de autoridad, que lo habilita para aplicar sanciones a los trabajadores que incurran en faltas o incumplimientos a sus obligaciones legales o contractuales, dentro de ciertas pautas o principios que lo restringen e imponen prudencia. (DIEGO, 2011, p. 228).

16 O termo compliance é traduzido do inglês como conformidade, observância, complacência ou submissão, substantivo que advém do verbo inglês to comply cuja tradução é adequar, cumprir, obedecer. (CUNHA; SOUZA, 2017, p. 76). 
Assim, pode-se citar que os programas de compliance estão ancorados em alguns aspectos ligados ao comportamento daqueles que estão envolvidos e, possuem relação com a empresa. Veja-se: i) observância; ii) comportamento; iii) cumprimento.

No que se refere a observância, é obrigatório que os intregrantes daquela relação de emprego, visto que é o objeto principal do artigo, devem observar as normas que foram veiculadas e utilizadas pela empresa. No que toca ao comportamento, as condutas, tanto da pessoa jurídica, como da pessoa física, devem pautar-se pela ética. O cumprimento está relacionado ao efetivo cumprimento em face das normas internas e externas adotadas pela empresa.

Luciano Santos Lopes e Renato Dilly Campos, explicam a importância dos programas de compliance, na delimitaçáo da responsabilidade de empregados e prepostos em eventuais ilícitos:

\begin{abstract}
Primeiramente, o compliance deve delimitar com precisão as tarefas pertinentes à cada preposto da empresa, bem como deve delimitar o funcionário responsável por sua fiscalização. Destarte, a instauraçáo do Compliance Criminal é um mecanismo eficaz (mas não absoluto) de delimitação da responsabilidade de cada preposto pela delegação de funções. Ainda, o Compliance eficaz deve identificar os agentes responsáveis pela fiscalização da conduta que produziu o resultado antijurídico. Deste modo, a instauração do Compliance Criminal auxilia a identificação dos agentes responsáveis pela conduta antijurídica, isentando (por muitas vezes) os demais envolvidos na cadeia executiva (geralmente, em razão de erro de tipo) da responsabilidade criminal que, sem o sistema, poderia lhes ser aplicada (LOPES; CAMPOS, 2017, p. 27).
\end{abstract}

Portanto, é fato que, os programas de compliance possuem uma grande relevância no trato de possíveis atos ilícitos, bem como no sentido de coibir condutas ilegais, os quais pautam-se na observância, cumprimento e comportamento daqueles que integram o vínculo de emprego e, que possuem algum tipo de relação com a pessoa jurídica.

\title{
3.1 O Compliance no Direito do Trabalho e a (in)adequaçáo ao poder empregatício
}

Sabe-se que os programas de compliance estão relacionados ao estado de conformidade, observância e cumprimento entre o que está descrito pelas normas, cartilhas, regulamentos e códigos de condutas das instituiçóes e, a efetiva conduta daqueles que possuem um vínculo empresarial com a instituição, neste caso um vínculo empregatício.

No âmbito trabalhista, os programas de compliance podem-se utilizar dos mesmos ensinamentos emanados da seara empresarial, visto que o programa de compliance será utilizado em face das necessidades e prioridades de cada empresa, pois cada empresa é passível de um determinado risco dentro do seu empreendimento.

Breno Novelli explica sobre a importância dos programas de compliance no âmbito das relaçóes trabalhistas: 
Mapeando as especificidades de cada núcleo organizacional, criar um ambiente transparente, sadio e respeitoso no trato interpessoal entre todos os funcionários, observando os ditames do complexo ordenamento jurídico trabalhista pátrio, passando, ainda, pela jurisprudência pertinente às relaçôes trabalhistas. Neste sentido, por exemplo, devem ser coibidas atitudes preconceituosas, abusos hierárquicos, além de obediência a critérios objetivos em contrataçôes, desligamentos e, claro, no trato entre colegas. Amplia-se, ainda, para a gestấo empresarial ético-sustentável, na qual haja a atuação incisiva para obedecer a legislaçáo posta, de forma a não suprimir direitos trabalhistas (NOVELLI, 2016).

Nesse sentido, a Controladoria Geral da União ${ }^{17}$ destaca que os programas de compliance ou programas de integridade possuem, ao menos duas principais funçóes: i) aplicar a cultura da conduta ética nas instituiçóes que utilizam de tal ferramenta, e, ii) atuar preventivamente em atos delitivos de qualquer natureza.

Assim, os programas de compliance tornam-se essenciais nas relação de emprego, visto que a sua principal função está diretamente relacionada a prevenção, bem como a correção de possíveis atos ilícitos, tanto do empregador, como pelo empregado.

O compliance trabalhista irá atuar principalmente na adoção de medidas, normas, regras, procedimentos internos e, também normas e procedimentos externas, para que haja uma maior segurança e licitude nas condutas daqueles que integram a relaçấo de emprego.

É importante destacar que para evitar a responsabilização da pessoa jurídica, que neste caso será do empregador, tanto na seara administrativa e judicial, a adoção dos programas de compliance tornam-se uma ferramenta essencial para as empresas, conforme preceito destacado pela Lei no 12.846/2013, designada "Lei Anticorrupção".

Trazendo o aspecto dos programas de compliance para o rol do poder empregatício, percebe-se que tal programa está diretamente relacionado ao poder que o empregador possui de dirigir e regular o seu empreendimento, o qual por meio de procedimentos instruirá os seus empregados em face das normas que aquela instituiçấo entende que são corretas e lícitas.

Nesse aspecto, tem-se na norma brasileira os poderes diretivos, regulamentar, fiscalizatório e disciplinar, enquanto na norma argentina, tem-se o poder de direção/ administração/organização e o poder disciplinar. Assim, verifica-se que os programas de compliance na norma brasileira é inerente ao poder regulamentar, visto que conforme elencado pela doutrina, tal poder possui como fundamento regular por meio de normas e procedimentos a atividade geral da empresa, em todos os aspectos necessários ao bom funcionamento do empreendimento.

$\mathrm{Na}$ norma argentina, os programas de compliance que possuem o mesmo contexto e forma de tratamento do Brasil, também se adequam dentro no poder empregatício, mas não no poder regulamentar como se adequa na norma brasileira e, sim, no poder de direção/ administração/organização da empresa, pois tal poder está relacionado a regulação por meio de procedimentos, regras, normas nas relaçóes de emprego da Argentina, ou seja, o poder de

17 Disponível em: <https://www.cgu.gov.br/Publicacoes/etica-e-integridade/arquivos/programa-deintegridade-diretrizes- para-empresas-privadas.pdf>. 
direção/administração/organização é inerente a toda a parte organizacional e procedimental a nível institucional da empresa.

Portanto, dadas as características expostas quanto aos programas de compliance e a sua (in)adequação dentro do poder empregatício nas relaçóes de emprego do Brasil e da Argentina, conclui-se que os programas compliance são uma das ferramentas utilizadas pela regulação dentro das relaçóes de emprego, como meio de prevenir os riscos, manter a licitude da operação e a higidez das atividades inerentes às atividades empregatícias, que no Brasil adequam-se dentro do poder regulamentar e, na Argentina adequam-se dentro do poder de direção/administração/organização.

\section{CONCLUSÃo}

O principal objetivo do presente artigo consistia em investigar a relevância dos programas de compliance no âmbito das relaçóes de emprego e, se de tais programas adequamse dentro do poder empregatício inerentes ao empregador, tanto na norma brasileira, como na legislação argentina.

Nesse rumo, analisou-se cada poder empregatício nas normas brasileiras e argentinas, bem como as suas divisóes internas. Sucessivamente, tratou-se da conceituação e aplicação dos programas de compliance nas relações empregatícios, que possui como principal medida a adoção de normas, regras, procedimentos e códigos de condutas internos, como também de normas externas, como meio de previnir e, corrigir a possíveis condutas e atos ilícitos daqueles que integram e possuem vínculo empregatício com a instituição empresarial.

Tratou-se também de diferenciar as relaçóes de trabalho e as relaçóes de emprego, dispondo que o poder empregatício é inerente somente em face daqueles que estão vinculados em uma relação de emprego, e que o poder empregatício é diretamente vinculado ao empregador, devendo, o empregado obedecer tais normas, primando pela legitimidade, boa-fé objetiva e legalidade de tais procedimentos.

Nesse norte, procurou-se responder aos seguintes questionamentos: i) os programas de compliance adequam-se dentro do poder empregatício da norma trabalhista brasileira e argentina; ii) os programas de compliance estão relacionados em qual ramificação do poder empregatício. Para responder a tais intentos, fez-se necessário utilizar tanto das normas, doutrinas e jurisprudências brasileiras, como das normas e doutrinas argentinas.

Diante da estrutura apresentada, a conclusão, ou seja, a confirmação da hipótese é que os programas compliance adequam-se no poder empregatício inerentes às relaçóes de emprego, que no Brasil adequam-se dentro do poder regulamentar e, na Argentina adequam-se dentro do poder de direção/administração/organização da empresas.

\section{REFERÊNCIAS}

ARGENTINA. Site do Ministerio de Justicia y Derechos Humanos. Disponível em: <http://servicios.infoleg.gob.ar/infolegInternet/anexos/25000-29999/25552/texact.htm> Acesso em 20 mar. 2020. 
BADARÓ, Gustavo Henrique; BOTTINI, Pierpaolo Cruz. Lavagem de dinheiro: aspectos penais e processuais penais. 3. ed. Sáo Paulo: Revista dos Tribunais, 2016.

BRASIL. Tribunal Regional do Trabalho da 13º Regiáo. RO: 00008692420185130008 0000869-24.2018.5.13.0008. Relator Ubiratan Moreira Delgado. Publicação: 19 set. 2019. Dsponível em:< https://trt-13.jusbrasil.com.br/jurisprudencia/759728723/recursoordinario-trabalhista-ro-8692420185130008-0000869-2420185130008/inteiro-teor759728736 ? ref=juris-tabs $>$. Acesso em 20 mar. 2020.

BRASIL. Implementaçáo de programa de compliance e seus impactos na área trabalhista. Disponível em:< https://www.direitonet.com.br/artigos/exibir/9732/ Implementacao-de-programa-de-compliance-e-seus-impactos-na-area-trabalhista $>$. Acesso em 20 mar. 2020.

BRANCHIER, Alex Sander; TESOLIN, Juliana Daher Delfino. Direito e Legislaçáo Aplicada. 3 ed. rev. e atual. Curitiba: Ibpex, 2006.

BRASIL. Constituição da República Federativa do Brasil de 1988. In: Vade Mecum. 22 ed. São Paulo: Saraiva, 2016.

BRASIL. Site do Planalto Central. Disponível em: <http://www.planalto.gov.br/ccivil_03/ constituicao/constituicaocompilado.htm> Acesso em: 03 mar. 2020.

BRASIL. Site do Planalto Central. Disponível em: <http://www.planalto.gov.br/ccivil_03/ decreto-lei/Del5452.htm> Acesso em: 03 mar. 2020.

CAIRO JÚNIOR, José. Curso de Direito do Trabalho. 11 ed. rev e atual. Salvador: JusPodivm, 2016.

CALVO, Adriana. Manual de direito do trabalho. São Paulo: Saraiva, 2013.

CASSAR, Vólia Bomfim. Resumo de direito do trabalho. 6. ed., rev., atual. e ampl. Rio de Janeiro: Forense, 2018.

CUNHA, Rogério Sanches; SOUZA, Renee. Lei Anticorrupçáo empresarial. Salvador: Juspodivm, 2017.

DELGADO, Maurício Godinho. Curso de direito do trabalho. 14 ed. São Paulo: LTr, 2015.

DIEGO, Julián A. de. Manual de Derecho del Trabajo y de la Seguridad Social. 8ª. ed. actualizada y ampliada. Buenos Aires: La Ley, 2011.

FREDIANI, Yone. Direito do Trabalho. 3 ed. Barueri: Manole, 2011. 
GRISOLIA, Julio Armando. Manual de derecho laboral. $7^{\mathrm{a}}$ ed. Ciudad Autônoma de Buenos Aires: Abeledo Perrot, 2016.

LOPES, Luciano Santos; CAMPOS, Renato Dilly. A omissão penalmente relevante e a função de garantidor do empresário. In: LOPES, Luciano Santos; MARTINS, Amanda Jales (orgs.). Direito penal econômico; tendências e perspectivas. Belo Horizonte: D’Plácido, 2017, p. 15 a 35.

NASCIMENTO, Amauri Mascaro. Curso de direito do trabalho. 26. ed. - São Paulo: Saraiva, 2011.

PEREIRA, Leone. Manual de processo do trabalho. 2. ed. São Paulo: Saraiva, 2013.

SILVA, De Plácido e. Vocabulário jurídico. 30. ed. Rio de Janeiro: Forense, 2013. 